\title{
Reform and Practice of "Five-in-one" Graduation Creation Mode of Fine Arts under the Perspective of Transformation and Development of Local Colleges*
}

\author{
Jun Sun \\ School of Fine Arts \\ Huanggang Normal University \\ Huanggang, China
}

\begin{abstract}
Constructing graduation creation (design) system with "five-in-one" pattern of "experiment teaching, professional competition, graduation (course) design, graduation field work (practice), graduation creation (design)" can better take advantage of regional resources through practical planning and empirical research and establish new platform of interaction between school and enterprise and the graduation creation (design) mode with integration of production, learning, research and application. It improves students' thinking of artistic creation and expressive ability; meanwhile, makes graduation design become joint point of teaching, scientific research and social practice and the service for local economy according to regional market demands.
\end{abstract}

Keywords-five-in-one; transformation and development; local colleges

\section{INTRODUCTION}

Fine arts major in applied colleges must "base on ability, keep students' dominant role and teachers' leading role and lay emphasis on application, integration, occupation, openness and innovation". As an innovation activity with close combination of theory and practice, graduation design reflects designers' comprehensive quality of theoretical level, innovation ability and professional practical ability. It is the final comprehensive teaching link in teaching plan of colleges, referring to a comprehensive training that students solve problems in production practice and technological innovation through knowledge that they have learned. As a concentrated and longterm practical teaching link, it plays a crucial role in training students' innovation and practical ability.

\section{NECESSITY TO CONSTRUCT GRADUATION CREATION (DESIGN) SY STEM}

\section{A. Requirements of Positioning and Service of Local Colleges}

In order to meet demands of local and regional economic

*Fund project:Practice brand construction project of transform at ion development of Huanggang Normal University: Reform and Practice of "Five-in-one" Graduation Creation (Design) Mode of Fine Arts Major under the Perspect ive of Transformation Development of Local Colleges (zxfz2016B018) construction and social development, applied colleges focus on training applied undergraduates. Compared with fine arts major in traditional universities, fine arts major in applied colleges lag behind in teaching staff, practice and experiment conditions and source of students. It must objectively consider conditions of school operation, make the most of local educational resources and strengthen teaching reform especially the reform of graduation creation (design) as well as construct reasonable graduation creation (design) system, in order to to train applied talents for local economic construction and form characteristics in the competition of higher education.

\section{B. Requirement of Training Talents Major in Fine Arts}

Local colleges should form characteristic major construction, establish sense of competition that creates brand through characteristics and seeks development through uniqueness and new idea of talent training and professional education. In order to serve local economic construction, the training objective of talents major in fine arts is: train applied high-level technical talents for local enterprises and front line of production management. Obviously, we should base on talent training characteristics of local colleges, reform traditional practical teaching system and construct new one as well as strengthen students' engineering consciousness and training of engineering practice ability, in order to train characteristic applied talents.

\section{Significance of Constructing Graduation Creation (Design) System}

As an indispensable part of talent training in colleges, graduation creation (design) is an important practical teaching link to train students' comprehensive quality and practical ability, the conclusion of talent training process and the preparation for practical work, and plays a vital role in checking and training comprehensive ability of talents. Effective measures are taken to strengthen the reform of teaching practice, improve the level of graduation creation (design) and train innovation and practical ability of applied talents through graduation design.

In order to meet demands of local and regional economic construction and social development, applied colleges focus on training applied undergraduates. Compared with fine arts 
major in traditional universities, fine arts major in applied colleges lag behind in teaching staff, practice and experiment conditions and source of students. It must objectively consider conditions of school operation, make the most of local educational resources and strengthen teaching reform es pecially the reform of graduation creation (design) as well as construct reasonable graduation creation (design) system, in order to to train applied talents for local economic construction and form characteristics in the competition of higher education.

\section{CONST RUCTION OF "FIVE-IN-ONE" GRADUATION CREATION (DESIGN) SYSTEM}

\section{A. Construction Principle of "Five-In-One" Graduation Creation (Design) System}

The construction of "five-in-one" graduation creation (design) system of fine arts major must follow the integral, shipshape and effective principle. Integral principle means integrating graduation creation (design) with theoretical teaching; shipshape principle means combining practical teaching links at different levels in and after class into a system well arranged to realize the training objective of graduation creation (design); effective principle means avoiding the repetition of contents in graduation creation (design) to save time and reduce expenditures.

\section{B. Construction Plan of "Five-In-One" Graduation Creation (Design) System}

The "five-in-one" practical teaching system consists of "experiment teaching, professional competition, graduation (course) design, graduation field work (practice), graduation creation (design)". It is the product that integrates experiment teaching with students' extracurricular practice, depends on the provincial level experiment platform of demonstration center of experiment teaching related to art and design of fine arts major and actively promotes the studio system and strengthens the experiment teaching idea of fine arts with "expansion, multiple dimensions, application and innovation", in order to train applied talents with profound cultural background, outstanding professional expertise, spirit and potential of artistic innovation. It is divided into three modules: basic skills, professional skills, technical application and innovation. Basic skill module includes experiment teaching and computer application and training; professional skill module includes practice and design; technical application and innovation module includes scientific and technological activities, social practice and labor training. Opportunities are created for students to practice independently, to integrate the training of knowledge, ability and quality. Meanwhile, links of practical teaching activities should run through the whole learning process. Each link must have explicit requirements of practical teaching and assessment methods. Attentions are paid to process assessment and evaluation of comprehensive quality, in order to ensure the quality of practical teaching and form progressive and well arranged practical teaching system.

\section{Actively Explore the Practice Mode with Interaction between College and Local Areas and the Integration of Production, Learning, Research and Application}

The integration of "production, learning, research and application" must be strengthened. Students and instructors can cooperate with local enterprises, public institutions and research and development institutions to utilize rich experience of technicians of enterprises. Designing projects according to demands of enterprises can solve problems like large quantity of students and difficult project design, so that instructors and students make common progress. Teachers can decompose projects developed through technical cooperation with enterprises into sub-projects that directly serve as topic of graduation creation (design), so many novel projects are obtained. Students from different disciplines and majors are organized to form teams of creation (design), in order to comprehensively research projects with wide range and heavy workload. Graduation creation (design) is taken as the joint point of teaching, scientific research and social practice. The goal of realizing "zero distance" employment of talents can be achieved through win-win mode between school and enterprise according to market demands. The graduation design mode that integrates production, learning and research can let students participate in technology implementation and scientific research and propose ideas and methods of solving problems. It shortens students' psychological distance with production practice and improves their ability and selfconfidence in solving problems independently. To sum up, to carry out practice, production practice or graduation design in modern industry can make students understand the society, characteristics, current situation and development prospect of industry, know about social demands for talents, their striving direction and social positioning and expand employment channel ahead of time. Enterprises formulate plans related to demand for talents according to physical truth and determine training objectives, quantity and course provision through consulting with colleges and scientific research institutions. Students can be arranged to practice in enterprises to know about organization structure, management mode, product development process and manufacturing technique and strengthen the combination of theory with practice. Some interns required by enterprises can be employed so that they will adapt to enterprises fast after graduation and develop products. It saves the time that students adapt to enterprises and avoids the situation that what students learn doesn't completely meet demands of enterprises. Meanwhile, it closely integrates school education with demands of enterprises and saves costs of enterprises to train graduates. Based on the graduation design that integrates production, learning and research, enterprises can invite researchers in universities to give technical guidance, improve the ability of enterprise in research and development of new products and the level of technicians as well as provide consultations for reform and development of enterprises. Furthermore, enterprises can provide students with practical problems to be solved urgently in production as topic of graduation design, make the best of human resource of graduates and precise instruments and equipment of universities to solve technical problems. 


\section{Closely Combine Graduation Course Design with Graduation Creation (Design)}

Bring graduation (course) design forward to the sixth semester and closely combine professional practice with graduation course design. Students determine the direction of graduation design before professional practice, look up for relevant information and discuss with the instructor as well as practice with problems. At the meantime, students are encouraged to take part in practical activities and cooperate with enterprises during internship period and bring project design in graduation course design through depending on scientific research projects or engineering projects. The interactive teaching of "understand practice through theory and promote theory through practice" can realize talent training objectives and be realized through "project-driven teaching", the teaching place of which is laboratory or studio. The theme is to carry out course design of actual project and design through project implementation. Students have explicit design direction once entering laboratory or studio. They are grouped and assigned with specific design tasks to design projects through teamwork in strict accordance with design procedures and specifications. They are required to design works with practical value. Students can experience the process through course design, digest professional knowledge and obtain ability of solving practical problems and ability of comprehensive application.

\section{E. Competition Activity and Scientific Research Innovation Training}

Competition activities and scientific research innovation training are important ways of improving students' comprehensive ability and necessary parts of practical teaching, mainly including: social investigations, discipline competition, scientific and technological innovation and academic activities as well as club activities. It vigorously promotes students' social practice and innovation activities and enriches school life. Opportunities are created for students in scientific and technological activities and social practice to make students make progress. Control regulations such as Regulations on Extracurricular Scientific and Technological Cultural Activities of College Students, Regulations on the Management of College Student Organizations ensure the quality of practical activities and train talents. According to teaching plan of each semester, homework exhibition and professional competition are organized through overall planning and arrangement. Extracurricular credit system is implemented. Students must take part in at least one professional competition above provincial level and complete social practice of at least 48 credit hours on school days. It will directly influence graduation if students fail to obtain corresponding credits.

\section{IMPROVE MANAGEMENT SYST EM OF GRADUATION CREATION (DESIGN) AND CARRY OUT DIVERSIFIED REFORM AND PRACTICE}

\section{A. Policies Must Be Personalized, Strict and Normative}

Revise and improve rules and regulations and plans and take students' employ ment pressure and enthusiasm in taking postgraduate entrance exams into full consideration.
Graduation creation (design) is coordinated with students employ ment and preparations for taking postgraduate entrance exams, to realize early deployment, arrangement, coordination and overall planning. Personalized policies should have strict specifications and requirements. The exhibition qualification of students who are absent from one third of the time for graduation creation (design) will be canceled, and they can retake it in set time. Graduates are required to sign letter of undertaking of graduation creation (design). Students who cheat and plagiarize will be punished after verification, such as don't award degree, delay graduation.

\section{B. Normalize Graduation Creation (Design) and Improve Three-Level Management System}

Management system at school, college and major levels led by principals is constructed and implemented to define management responsibilities. Practical teaching and equipment management office manages graduation creation (design) and formulates policies, systems and provisions of it and give macro guidance and check it. The college executes provisions on graduation creation (design) and formulates enforcement regulations according to characteristics of majors in this college. The major manages daily work of students who participate in graduation creation (design) under the leadership of college, formulates or revises professional teaching documents such as Outline of Graduation Creation (Design) and Guidance on Graduation Creation (Design) for instructors and students to use.

\section{CONCLUSION}

According to different characteristics of training students at different stages of colleges, the "five-in-one" graduation creation (design) training pattern that integrates production practice, course design, professional competition, graduation field work and graduation design is provided to train applied talents of fine arts with good attitudes, ambitious goal, strong will, sharp mind and innovation quality. Graduation design is systematic. Except for the reform in this link, it should be integrated with teaching links of college days. The training of students' practical ability depends on the joint efforts of all teachers.

\section{REFERENCES}

[1] Wang Zhenjinag, Xu Wubin, Huang Weijian. Seamless Joint of Education Service Project with "Three-in-one" of Practice, Design and Employment [J], Education Forum, 2012, (2): 7-9

[2] Zhou Xitang, Li Run, Xuan Zhengnan. "Three-in-one” Applied Talent Training Mode and Its Practice [J], Education Forum, 2013, (5): 217 219

[3] Wu Xiao. Exploration and Practice on Constructing New Pattern of Engineering Ability Training $[\mathrm{M}]$, Changsha: Hunan Science and Technology Press, 2003: 346-350

[4] Cheng Shuiyuan. Meditations on University Management [M], Beijing: Higher Educat ion Press, 2011: 12 